\title{
«Зүрхэн толтын тайлбарын» зохиогч үзэмчин хүн хэмээсэн нь (= Об удзумчинском авторе сочинения «Комментарий к „Сердечному покрову“»)
}

\section{Нараниңэиэг Дамбийхорлоо ${ }^{1}$}

${ }^{1}$ Институт языка и литературы Академии наук Монголии (д. 54a, проспект Энхтайван, 13 квартал, округ Баянзурх, 13330 Улан-Батор, Монголия); Хулунбуирский университет (д. 83, ул. Шуэ фу, район Хайлар, 021008 Хулунбуир, АРВМ, КНР) доктор филологических наук, профессор, заведующий секцией; приглашенный профессор

iD 0000-0003-1299-317X. E-mail: narantsetseg_d@mas.ac.mn

\author{
(C) КалмНЦ РАН, 2021 \\ (c) Наранцэцэг Д., 2021
}

Аннотация. Введение. В статье рассмотрена история изучения одного из важнейших памятников монгольского языкознания - монгольского грамматического сочинения «Комментарий к „Сердечному покрову“, именуемый „Небесная молитва“» и его текстологическое исследование и публикация, выполненные П. Б. Балданжаповым. Цели и задачи исследования заключаются в оценке работы П. Б. Балданжапова, выявлении его вклада в изучение монгольских грамматик, а также в уточнении имени автора данного сочинения - удзумчинского Молон-равжамбы. Для решения поставленных задач применялись общенаучные методы и подходы: историко-сравнительный, историко-описательный, а также специальные методы источниковедения и критического анализа текста. Материалами и источниками для написания статьи послужили монография П. Б. Балданжапова «Зурхний толтын тайлбури» (Улан-Удэ, 1962) и публикации других авторов по данной теме, а также монгольские исторические источники. Результаты. Публикация П. Б. Балданжапова является $\backslash$ наиболее законченным и полным исследованием данного сочинения по монгольской грамматике, высоко оцененным как монгольскими, так и зарубежными учеными, широко используемым ими в исследованиях по истории монгольского языка и языкознания. П. Б. Балданжаповым на основе текстологического анализа нескольких сочинений убедительно доказано, что автором данного грамматического сочинения является молом-равжамба Данзандагба. Существуют несколько точек зрения на происхождение Данзандагвы. Автором данной статьи вводится новый материал, почему автора этой грамматики звали также удзумчинский Молом-равжамба.

Ключевые слова: удзумчин, Молом-равжамба, Данзандагба, «Зурхний толт», Балданжапов, монгольская грамматика

Для цитирования: Наранцэцэг Д. «Зүрхэн толтын тайлбарын» зохиогч үзэмчин хүн хэмээсэн нь (= Об удзумчинском авторе сочинения «Комментарий к „Сердечному покрову“») // Монголоведение. 2021. Т. 13. № 4. С. 685-693. (На монг. яз.). DOI: 10.22162/2500-1523-2021-4-685-693 


\title{
The Commentary on Jirüken-ü tolta ('Cover of the Heart') and Its Üzemchin Author Revisited
}

\author{
Narantsetseg Dambiikhorlo ${ }^{1}$
}

${ }^{1}$ Institute of Language and Literature, Mongolian Academy of Sciences (54A, Enkhtaivan Ave., Block 13, Bayanzürkh District, 13330 Ulaanbaatar, Mongolia); Hulunbuir University (83, Xuefu Rd., Hailar District, 021008 Hulunbuir, Inner Mongolia, People's Republic of China)

Ph. D. (Philology), Professor, Head of Department; Visiting Professor

iD 0000-0003-1299-317X. E-mail: narantsetseg_d@mas.ac.mn

(C) KalmSC RAS, 2021

(C) Narantsetseg D., 2021

\begin{abstract}
Introduction. The present article discusses the history of one of the most important monuments of Mongolian linguistic heritage "The Commentary on 'Jirüken-ü tolta-yin tayilburi", a grammar treatise, which was published by Purbo Baldanzhapov with the textological analysis of the source. The author aims to study Baldanzhapov's work and his contribution to the study of Mongolian grammar treatises; also, to clarify the authorship of the source in question. Materials and methods. For the purpose, most appropriate were general scientific methods and approaches, such as historical-comparative and historical-descriptive, as well as special methods of source studies and critical analysis of the text. Baldanzhapov's monograph "Zurkhny Toltyn Tailburi” (Ulan-Ude, 1962) and publications of other authors on the subject, as well as Mongolian historical sources were used as the database of the research. Results. Baldanzhapov's «Commentary to "the Zurkhen tolt": Mongolian Linguistic Text of the Eighteenth Century» is, to date, the most complete and exhaustive study of the Mongolian grammar treatise, highly appreciated by scholars in Mongolia and outside the country, and widely used by researchers on the history of the Mongolian language and linguistics. Having undertaken the textual analysis of several works, the scholar convincingly argued that the author of this grammatical work was Molom Ravjamba Danzandagva. However, there are several points of view on Danzandagva's background; the present author introduces new data that sheds light on the author of the "The Commentary on 'Jirüken-ü tolta-yin tayilburi'" who was also named Uzemchin Molom Ravjamba.
\end{abstract}

Keywords: Uzemchin, Molom Ravjamba, Danzandagva, Zurkhenii tolt, Purbo Baldanzhapov, Mongolian grammar

For citation: Narantsetseg D. "The Commentary on Jirüken-ü tolta ('Cover of the Heart') and Its Üzemchin Author Revisited. Mongolian Studies (Elista). 2021; 13(4): 685-693. (In Mong.). DOI: 10.22162/2500-1523-2021-4-685-693

\section{Оршил}

Монгол хэл шинжлэлийн чухал дурсгал «Зүрхэн толтын тайлбар „Огторгуйн маани“» хэмээх хэлзүйн бичгийг дэлхийн монгол судлаач олон эрдэмтэн мэргэд анхааран судалж, анхлан Урад гүүш Билгүүндалай, Авгын занги Лхамсүрэн, Алшаагийн Агваандандар лхарамба, Буриадын Номтын Ринчен, Халхын Тогтохтөр ван, Онход Жамьян гүн нарын олон мэргэд хэл шинжлэлийн зохиолууддаа өргөн ашиглаж иржээ. Хожимхон нь Оросын нэрт монголч эрдэмтэн Я. Шмидт, А. А. Бобровников, А. М. Позднеев нар судалж, профессор А. М. Позднеев «Огторгуйн маанийн» уг эхийг нийтлүүлж олны хүртээл болгож байв. 


\section{Материалы IV Международного семинара «Письменное наследие \\ и актуальные проблемы истории и культуры монгольских народов», посвященного 100-летию со дня рождения Пурбо Балдановича Балданжапова}

Харин ХХ зууны дунд үеэс л энэ зохиолыг ганц сэдэвт зохиолын түвшинд өргөн хүрээнд судалсан дорвитой судалгааны бүтээлүүд гарч эхэлсэн юм. Тухайлбал, Германы нэртэй төвөд судлаач, монголч эрдэмтэн профессор М. Таубе, Буриадын нэрт монголч эрдэмтэн П. Б. Балданжапов, монголын хэл шинжлэлч профессор Т. Пагба нарын ул суурьтай нарийн чамбай ганц сэдэвт зохиолууд нь «Зүрхэн толтын тайлбар „Огторгуйн маанийн“» судалгааг урагш ахиулсан чухал бүтээл болж чадсан билээ. Эдгээр эрдэмтдийн бүтээлээс «Зүрхэн толтын тайлбарыг» эх бичиг судлалын өндөр түвшинд хийсэн профессор П. Б. Балданжаповын судалгааг онцлон дурдах нь зүй ёсны хэрэг юм.

Монголын түүх, тулгуур бичгийн судлалын томоохон эрдэмтэн, ЭнэтхэгТөвөдийн анагаах ухааны бичгийн өв болон Ганжуур, Данжуурын бурхны шашны каноник цуглуулгын эрдэм шинжилгээний ажлыг үндэслэгч Пурбо Балданович Балданжапов «XVIII зууны үеийн монгол хэлзүйн бичиг „Зүрхэн толтын тайлбар“» [Балданжапов 1962] хэмээх ганц сэдэвт зохиолоо 1962 онд нийтлүүлжээ.

Профессор Балданжаповын энэ ганц сэдэвт зохиолын үндсэн бүтэц нь дэлгэрэнгүй удиртгал өгүүлэл, буриадын Агын дацанд барлуулсан «Зүрхэн толтын тайлбар үсгийн эндүүрлийг арилгагч огторгуйн маани хэмээгдэгч оршив» гэсэн 36 хуудас судрын гэрэл зураг, орос хэлний орчуулга, орчуулгын тайлбар, хавсралт хэсгээс бүрдэнэ. Хавсралтын хэсэгтээ «Монгол үсгийн толтоос өчүүхэн заавар болой», «Монгол үсгийн ялгал ба махбодын өгүүхэн товч нугууд болой» гэсэн Билгүүндалайн хэл зүйн хоёр чухал зохиолын модон барын эхийг гэрэл зургаар хэвлүүлсэн нь энэ бүтээлийг эрдэм шинжилгээний ач холбогдлыг улам төгөлдөржүүлжээ.

Профессор Балданжаповын сурвалж бичиг судлах сонгодог аргазүйн дагуу хийсэн энэхүҮ ганц сэдэвт зохиол нь бичвэр судлалын ажилд баримтлах хэв загвар, арга туршлага болсоор ирснийг дотоод гадаадын эрдэмтэд өндрөөр үнэлж, зохиол бүтээлдээ онцлон тэмдэглэдэг тул энэ зохиолын агуулгыг дахинтаа танилцуулалгүй, харин түүний судалсан «Зүрхэн толтын тайлбар „Огторгуйн маани“»-ийг зохиосон Молом равжамба Данзандагвыг яагаад Үзэмчиний молом равжамба хэмээх болсон тухайд анхаарлаа хандуулъя.

\section{«Огторгуйн маанийг» зохиогч Молом равжамба Данзандагва гэж хэн бэ?}

«Зүрхэн толтын тайлбар „Огторгуйн маанийг“» зохиосон Молом равжамба Данзандагва Төвөдийн Амдо мужийн Рүжа аймгийн нэгэн бага ноёны хөвүүн болон мэндэлжээ.

Тэрбээр хүүхэд ахуй цагтаа нутгийнхаа Рүжа хийдэд шавилан сууж байгаад тэндээсээ Сэра хийдэд очин судар, тарнийн номд суралцаж, зэргээр Лхаст морилон саатаж Лхасын их ерөөл буюу цагаан сарын их ерөөл хурах цагаар өөрийн үеэл хоёр ихэр дүүгийн хамтаар равжамбын дамжаа барьсны учир олонд Молом равжамба хэмээн алдарших болжээ. Энэ тухай зарим сурвалжид «Лхас молом равжамбын дамжааг тэнцэх ханьгүй барьж яруу алдар нь ихэд дэлгэрсэн...» гэжээ [Пунсаг 2006: 412]. Энд гарч байгаа «Молом Равжамба» хэмээх зохиогчийн зэрэг хэргэмийн нэрийн утгын хувьд Молом гэдэг нь 
ерөөл гэсэн утгатай төвөд үг бөгөөд цагаан сарын шинийн нэгнээс 15-ныг хүртэл Лхасын их ерөөл хурах үеэр равжамбын дамжаа барьсан тул «Молом равжамба» хэмээн нэрийдэх болсон ажээ.

Бас зарим сурвалжид түүнийг «Жанжаа хутагтын Молом равжамба» гэх буюу тэрбээр өөрөө ч зарим нэг зохиолынхоо төгсгөлийн үгэнд «Жанжаа гэгээн эрдэнийн танхай шавь молом равжамба Данзандагва» хэмээн бичсэн байх бөгөөд энэ нь Данзандагва 1710 оны орчимд Долоннуур сүмд одож Жанжаа хутагт Агваанчойдоныг (1642-1714) багш барьсны учир ийнхүү хамаатуулан хэлсэн бололтой.

\section{Молом равжамба Дандандагвыг Үзэмчиний молом равжамба хэмээсэн} нь

Данзандагвын мэндэлсэн нутаг орон нь эртнээс нааш төвөд, дээд монгол, монгор, ойрад, хошууд, хотон олон угсаатан хаяа хэдрэн залгаж суусаар ирсэн газар бөгөөд Данзандагва төвөд үндэстэн үҮ, хотон үндэстэн үҮ, монгол үндэстэн ҮҮ гэдэг бол анхаарууштай чухал асуудал мөн. Үүний дотроос Молом равжамбыг яагаад Үзэмчиний Молом равжамба гэж нэрлэв гэдэг бас сонирхол татаж байна.

Эрдэмтдийн судалгаанаас үзвэл түүнийг Алшаа нутгийн хүн, Зүүн Үзэмчин хошууны хувилгаан лам байсан, Баруун газар буюу Төвөд орноос гаралтай хүн гэсэн гурван санал зонхилж иржээ.

Бидэнд энэ хэр мэдэгдэж буй баримтаар эн тэргүүнд Буриадын билигт эрдэмтэн Номтын Ринчин (1821-1907) «Яруу хэлний хүрхрэл» хэмээх зохиолдоо «Бас нэгэн үед мэргэдийн дээд ойрад молом равжамба лам Данзандагвабалсамбуу бээр Бодь мөрийн зэргийн улаан хөтөлбөрийг монгол хэлнээс төвөдийн хэлэнд орчуулбай» хэмээн мэдээлсэн бөгөөд энд Данзандагвыг ойрад хүн гэж онцлон хэлжээ [Ринчин: 21b].

Манай хэл утга зохиолын голлох эрдэмтэн академич Ц. Дамдинсүрэн [Мандах 1990: 198], Д. Төмөртогоо [Төмөртогоо 1981: 6-7] нарын зэрэг судлаачид Данзандагвыг Алша нутгийн хүн гэж үзсээр иржээ. Энэ тухайд эрдэмтэн Т. Пагва «Түүнийг Алшаа нутгийн Данзандагва гэж зарим зохиолд дурдсан байвч Алшаагаас өөр нутгаас ирээд сууж байсан хүн бас байж болох юм» гэсэн тайлбар хийсэн байдаг [Пагва 1995: 13].

Академич Д. Цэрэнсодном багш «Данзандагвын намтар, цадиг хийгээд түүний явдал мөрийн байдлаас шинжилж үзвэл тэрээр Төвөдөөс Монгол нутагт шашин дэлгэрүүлэхээр залрахдаа Авгын нутгийг дамжин Үзэмчинд ирсэн байдалтай байх тул Алшаа нутагт сууж тэр нутгийн хүн гэж алдарших болсон гэх баримт олдохгүй байна. Тэгвэл яагаад түүнийг Алшаа нутгийн хүн гэх болсон юм бэ? гэсэн асуулт гарч болно» [Цэрэнсодном 2021: 57] гээд Данзандагвын уугуул нутаг усыг тодлохоор хичээнгүйлэн шинжилсэн Молом равжамба Данзандагвын «Богд Чойжи-Одсэр бээр зохиосон Зүрхний толтын тайлбар үсгийн эндүүрлийн харанхуйг арилгагч Огторгуйн мани» хэмээх өгүүлэлдээ: «Тэрбээр Дандар лхаарамбын „Хэлний чимэг“ хэмээх зохиолын төгсгөлийн үгэнд „...Алшаагийн молом равжамба Дандар бээр бичив“ хэмээснийг зарим бичвэрт эл хоёр равжамбын адил зэрэгтэй эрдэмтдийг хутгаж, хувиргасан явдалтай холбоотой байж магадгүй болов уу гэж үзэж 


\section{Материалы IV Международного семинара «Письменное наследие \\ и актуальные проблемы истории и культуры монгольских народов», посвященного 100-летию со дня рождения Пурбо Балдановича Балданжапова}

байна. Үүнийг гэрчлэх баримт гэвээс зарим нэгэн судлагч ч энэ хоёр монлом равжамба цолтныг хооронд нь хутгаж будилсан зүйл ажиглагдаж байна». Жишээлбэл На. Тэмцэлт «Огторгуйн маанийн зохиогчийг Алшаагийн молом равжамба Данзандагва болно» гэж «Үзэмчин Данзандагвын тухай өчүүхэн шинжлэл» хэмээх өгүүлэлдээ бичсэн ажээ [Цэрэнсодном 2021: 57]. Үүнээс гадна Үзэмчин нутагт өргөн дэлгэрсэн Дансүрэн Лхарамбын домогт түүнийг Дандар (1758-1886) Лхарамбатай уулзаж байсан мэтээр домоглосон нь үнэн хэрэгтээ бодит түүхтэй үл авцалдах зүйл болно» хэмээн бичжээ [Бөххад, Жадамба 1989: 75].

Бидний энэ хэр олж үзсэн баримтаар түүнийг Баруун газар буюу Төвөд орны хүн байсан гэх мэдээг занги Лхамсүрэн 1903 онд анх барлуулж, 1913 онд Шинэ толийн хорооноос дармаллаж хэвлүүлсэн «Монгол үсгийн ёсыг тодорхойлон гаргасан алтан толь хэмээгдэх оршив» хэмээх хэлзүйн бичгийнхээ эхэнд дурдсан байна. Үүнийг эшлэн танилцуулбал: «Анх монгол үсгийг Баруун газрын их бандида лам Гунгаажалцаны гэгээнтэн тогтоон зохиосон Зүрхний толт хэмээх судраас эхэлж үүсгэн журамласан ба хойно мөн газрын Молом ламын зохиосон „Зүрхний толтын тайлбар огторгуйн маани“ хэмээх судрыг гол болгож хэрэглэсээр...» гэсэн байна [Лхамсүрэн 1913: 1-р хуудас 6-p мөр]. Бидний бодоход энд гарч буй мөн газрын Молом равжамба гэж бичсэнээс үндэслэн түүнийг ч мөн Сажа бандидатай адил төвөд хүн гэж үзсэн бололтой байна. Гэвч энд өгүүлж буй мөн газрын Молом равжамба хэмээсэн нь Данзандагвыг Баруун газар буюу Төвөдийн газар равжамба цол хүртсэнийг хэлсэн хэрэг байж болох юм. Дээр өгүүлсэн энэ мэт баримт хийгээд хуучин мэргэдийн ам дамжсан элдэв хууч ярианы мөрөөр Үзэмчиний түүх соёлын зүтгэлтэн профессор М. Дугар [Дугар 1987: 26], На. Тэмцэлт [Тэмцэлт 1984: 31], Ү. Мандах [Мандах 1990: 198] зэрэг судлагч ч төвөд гарлын хүн байжээ гэсэн саналыг дэвшүүлж иржээ. Юутай ч гэсэн эдгээр судлаачид Данзандагвын намтарт холбогдох чухал материалыг олж илрүүлсний хүчээр түүнийг энэ яваа насных нь амьдралын түүх төдийгүй эрт урьдын төрлийн цадигт холбогдох нэн сонирхолтой олдворыг нээн илрүүлсэн нь яах аргагүй судалгааны нээлтийн чанартай шинэ зүйл гэж хэлж болох юм. Энэ нь:

1. «Хүрээ сүмийн товч түүх».

2. «Эцсийн хязгаар дахь шашныг тодруулан зохиогч уулын цорж лам Лувсанданзаны цадиг сүсгийн үүдийг нээгч хэмээх оршивой» гэсэн хоёр сурвалж бичиг болно.

Энд гарч буй Хүрээ сүмийн тухай зохиолын дэлгэрэнгүй нэр нь: «Шилийн гол аймгийн Зүүн Үзэмчин хошууны ламын хүрээ сүмийн гэгээн ба сүмийн дөхөм түүх» гэсэн бичмэл судар болно. ЭнэхүҮ Хүрээ сүмийг равжамба Данзандагвын удаах дүр Үзэмчин түшээ гүнгийн хөвүүн Гончигдаш цагаагчин үхэр (1781) жил байгуулжээ.

Монлом ламын Хүрээ сүмийг анх байгуулахдаа гэр дугануудыг хүрээлэн буулгах байдалтай суурьшуулсан тул ийнхүү нэрлэх болсон гэж судлаачид тэмдэглэсэн байна. Энэ сүм равжамба Данзандагвын өөд болсноос хойш 50 орчим жилийн дараа байгуулагдсан боловч тэр ламын эд хөрөнгөөс энэ сүмд өргөл болгон хадгалж байсан бололтой юм. Тухайлбал Данзандагвын ариутган шүүлгэж Бээжинд барлагдсан шунхан Ганжуурын иж бүрэн 108 боть ном энэ 
сүмд хадгалагдаж байжээ. Данзандагвын уншиж хэрэглэж байсан тэр адистид оршсон Ганжуур номыг манай улс номын сандаa 1923 онд залж ирсэн түүхтэй.

Бас нэгэн баримт сөхөж үзвээс судар бичгийн хүрээлэнгийн гишүүд 1921 оны арван хоёр сарын шинийн гурванд хуралдаж тус хүрээлэнгийн гишүүн Бат-Очир, Дашням нарыг Үзэмчин, Цахарын хошуу нутгаар ховор ном судар эрэн сурвалжлах ажлаар гурван сарын хугацаагаар томилон ажиллуулах шийдвэр гаргажээ. Энэ ёсоор Дашням гүн Шилийн голын чуулганы баруун, зүүн Үзэмчин, Цахарын нутгаар зорчиж олон чухал ном судар олсны дотор Үзэмчин Молом ламын хүрээнээс монгол үсгийн шунхан Ганжуур 111 ботийг 1923 онд залж ирснийг онцлон дурдсан байна. Энэ Ганжуур номын тухай Үзэмчиний судлагч П. Дугар «Үзэмчин Данзандагва хийгээд „Огторгуйн маани“» хэмээх өгүүлэлдээ: «...Үзэмчиний Ширээт сүмийн Гончиг гэдэг хүмүүн Молом ламын хүрээний монгол хэлний Ганжуурыг арваад үхэр тэргэнд ачаалаад Монгол Улсад хүргэж өгсөн гэдгийг Хүрээ сүмийн зарим өвгөн лам нар одоо болтол тодорхой мэдэж байна» хэмээжээ [Дугар 1987: 29].

Энэхүу 1717-1720 оны хугацаанд Бээжинд барлагдсан монгол шунхан Ганжуурыг Молом равжамба Данзандагва 1720 хэдэн оны үед Үзэмчин ван Сэдэндонровын (1961-1733) ордонд сууж Ганжуур номлож байсныг судлаачид бас тэмдэглэсэн байдаг [Пунсаг 2017: 167; Дугар 1990: 26].

Ташрамд өгүүлэхэд Данзандагвын уншиж, номлож байсан тэр Ганжуур ном бол өнөөгийн Монгол Улсын Үндэсний номын санд нандигнан хадгалагдаж байгаа 108 боть шунхан Ганжуур мөн хэмээж академич Д. Цэрэнсодном багш нэгэнтээ батлан хэлсэн билээ [Цэрэнсодном 2021: 59].

Академич Ц. Дамдинсүрэн «Монгол Ганжуурыг манай Судар бичгийн хүрээлэн 1923 онд сольж авсан» гэж мэдээлжээ. Энэ нь манай талаас хүрээ барын төвөд Ганжуурыг хариу барьсан болохыг хэлж байгаа бололтой.

Мөн Үзэмчиний ахмад судлагч Н. Бөххад өөрийн сахилын нэр болох Агваанлавсүм гэдэг нэрээр гаргасан „Лам эрдэмтэд, сурвалж бичгийн тухай судалгааны өгүүллийн түүвэр“-тээ: „Монгол, хятад хэлээр уламжилж ирсэн эрт өдгөөгийн олон баримтуудыг уялдуулан үзэж улмаар Хөхнуур хавийн газар нутгаар аялж, судалгаа хийж Рүжа хийдийн лам хувраг тэргүүтэн цөөнгүй хүмүүстэй уулзаж баримт нотолгоогоо баталгаажуулсны үндсэнд Данзандагвын уг гарал нь Цагаан монгол хэмээн нэрийдэгч монгор угсааны хүн байсан гэж тодорхойлжээ“» [Агваанлавсүм 2015: 14-30]. Данзандагвыг төрөлхийн монгол хэлтэн буюу монгол үндэстэн хүн байсан гэхийн хамгийн баримт сайтай бодитой баталгаа гэвэл түүний монгол хэлээр туурвисан олон зохиол бүтээлүүдээс бидний гарт энэ хэр олдоод байгаа «Зүрхний толтын тайлбар огторгуйн маани», «Цагаан даяанчийн намтар» зэрэг зохиолын хэл найруулга, нэр томьёо, илэрхийлсэн үзэл санааг ажиглавал яалт ч үгүй монголчуудын ахуй сэтгэлгээний шинж тэмдэг тодорхой ажиглагддаг юм.

Данзандагва нар үзэмчиний газар чухам хэдүй үед ирсэн нь тодорхой бус боловч 1680-д оны орчим морилсон байж магадгүй гэж зарим судлагчид таамаглаж байна. Тухайлбал, судлагч П. Дугар «Цагаан лавайн эгшиг» хэмээх зохиолд өгүүлсэн баримтыг үндэслэн үзэмчиний тойн гүүш Лхагважамцыг хөхөгчин үхэр жил (1685) мэндлэхэд Данзандагва нэр хайрлаж байсан тул энэ үед молом равжамба монгол нутагт нэгэнт морилон ирж суурьшсан байсан бололтой гэж үзжээ [Дугар 1987: 27]. 


\section{Материалы IV Международного семинара «Письменное наследие \\ и актуальные проблемы истории и культуры монгольских народов», посвященного 100-летию со дня рождения Пурбо Балдановича Балданжапова}

«Шилийн гол аймгийн Зүүн Үзэмчин хошууны ламын хүрээ сүмийн гэгээн бас сүмийн дөхөм түүх» (хураангуй нэр нь «Хүрээ сүмийн товч түүх») хэмээх судлаач Н. Бөххадын цуглуулгаас 2015 онд олж үзсэн, зохиогч нь тодорхойгүй гар бичмэл судрын хуулбарт «Тэндээс тэр лам Данзандагва, Ларган Какод ба бусад нэгэн шавьтай гурвуул баруун Хуучдыг дамжсаар Үзэмчин хошуунд ирээд Чин ван Сэдэндонров лугаа лам өглөгийн эзэн болоод Улаан хаалгын элсэнд Агваансодов дор багш шүтэгдэж шашин амьтны тусыг үйлдсэн болой» гэж буй [Хүрээ сүмийн товч түүх].

Бас өөр нэгэн сурвалжид: «...Их журган ба чуулган даргаас улам тушаасныг дагаж байцааваас манай хошууны молом равжамба Данзандагва Баруун зуугийн оронд олон жил сууж эрдэм номыг ихэд сайтар сураад, ер номоос өөр зүйл үгүй судар тарнийн ном алиныг боловч шавь нартаа сургуульд уйдаж чилээхгүй хошууны олон хуврагуудад их номоор чандалж он удтал суусан ажгуу» хэмээжээ [Пунсаг 2006: 412].

\section{Дүгнэлт}

Дээр өгүүлснийг товчлон хэлбэл «Огторгуйн маанийн» зохиогч Данзандагвын зохиол бүтээлийг XX зууны дунд үеэс судалж нийтлүүлсэн үе үеийн олонх эрдэмтэд «Шилийн голын чуулганы Үзэмчин хүн» гэж үзсээр иржээ. Учир нь гэвэл Данзандагва Үзэмчин газар 1683-1684는 оны орчим үед ирж суурьшин сүүлийн хэдэн жил Долоннуурт сууж байсныг эс тооцвол 40 гаруй жил Үзэмчин нутагт аж төрсөн тул энэ нутгийн суугуул иргэн болсон тул Шилийн голын чуулган даргын албан бичиг баримтад манай хошууны лам молом равжамба Данзандагва гэсэн байх агаад Данзандагва ч зүүн Үзэмчинг «өөрийн хошуу» хэмээн дурдсан зүйл бас бий. Тийм учраас Төвөд, Монголын зааг дахь Хөх нуурын өндөрлөг хавийн газар түүний уугуул нутаг нь мөн боловч Үзэмчин зүүн хошуу Монлом ламын суугуул нутаг нь мөн гэж хэлж болох юм.

\section{Ном зүй}

Агваанлавсүм 2015 - Агваанлавсүм. Лам эрдэмтэд, сурвалж бичиг судалгааны өгүҮллийн түүвэр / редактор Д. Наранцэцэг. Улаанбаатар: Адмон, 2015. 691 х.

Балданжапов 1962 - Балданжапов П. Б. Jirüken-ü tolta-yin tayilburi. Монгольское грамматическое сочинение XVIII века / Монгольский текст и перевод. Введение и примечание. Улан-Удэ: Бурятск. кн. изд-во, 1962. 136 с.

Бөххад, Жадамба 1989 - Bökeqada, Jadamba digelbe. Üjümüčin domuү-ud. Sili-yin qota, 1989. $356 \mathrm{x}$.

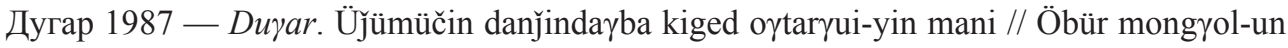
neyigem-ün sinjilekü uqayan. 1987. № 4. X. 26-34.

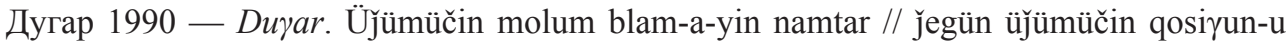
ulus törü-yin jöblelgen-ü soyul teüke-yin alban ger. Uliyasutai, 1990. 106 x.

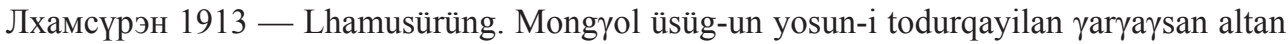
toli kemegdekü orusibai. Yeke küriyen $\gamma$ ajar büküi sine toli-yin qoyin-a-ača ... darumal

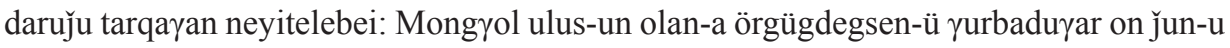
segül sarayin sineyin nigen-ü edür-e. Yeke khuriy-e, 1913. $27 \mathrm{~h}$.

${ }^{1}$ «Цагаан лавайн эгшиг» хэмээх сударт үзэмчний гүүш тойн Лхагважалсаныг хөхөгчин үхэр жил (1685) мэндлэхэд түүнд Данзандагва нэр хайрлаж байсан гэх мэдээ бий. 


\section{Монголоведение • Mongolian Studies • $2021 \bullet$ T. 13 • № 4}

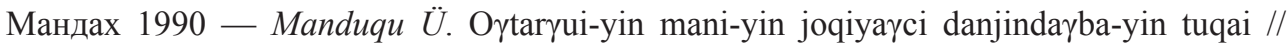

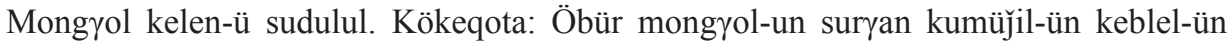
qoriy-a, 1990. X. 198-210.

Пагва 1995 - Пагва T. Зүрхэн толтын тайлбарыг шинжилсэн тухай. Улаанбаатар, $1995.58 \mathrm{x}$.

Пунсаг 2006 - Пунсаг А. Үзэмчиний Молом равжамбын түүхэнд холбогдох нэгэн

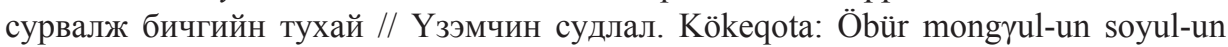
keblel-ün qoriy-a, 2006. X. 411-417.

Пунсаг 2017 - Пунсаг A. Үзэмчиний мэргэн хамба Санжаа-Ишжамцыг алба татвараас чөлөөлсөн нэгэн албан бичгийн тухай // Үзэмчин судлал / эмхэтгэсэн Д. Наранцэцэг. Улаанбаатар: 2017. Х. 164-170.

Ринчин — Ринчин Н. Degedü šasin erdeni ber mongyol oron-i tügegülügsen uð-i üjegülügsen irayu kelen-ü kürkirel neretü orusibai. Xyl., 27 f. // Центр восточных рукописей и ксилографов Института монголоведения, буддологии и тибетологии СО РАН. МФ. Инв. № БМ-658.

Төмөртогоо 1981 - Төмөртогоо Д. XVIII зууны үеийн Алшагийн эрдэмтэн рабжамба Данзандагвын зохиосон «Зүрхэн толтын тайлбар үсгийн эндүүрлийн харанхуйг арилгагч огторгуйн маани» хэмээх хэл зүйн бичиг // Монгол хэл шинжлэлийн түүхэн уламжлал ба онолын үндэс. Улаанбаатар: Улсын Хэвлэлийн газар, 1981. $162 \mathrm{x}$.

Тэмцэлт 1984 - Teтес̌eltü Na. Üjümüčin danǰindayba-yin tuqai öčüken sinǰilel // Öbür

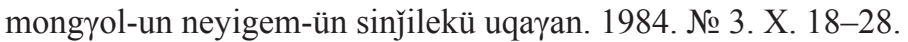

Цэрэнсодном 2021 - Цэрэнсодном Д. Молом равжамба Данзандагвын «Богд ЧойжиОдсэр бээр зохиосон Зүрхний толтын тайлбар үсгийн эндүүрлийн харанхуйг арилгагч Огторгуйн мани» // Монгол хэл шинжлэлийн үнэт дурсгалууд. Улаанбаатар: Мөнхийн үсэг, 2021. Х. 55-94.

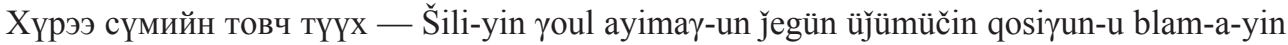
küriy-e süm-e-yin gegegen kiged süm-e-yin döküm teüke. Mns. Н. Бөххадын хувийн цуглуулга.

\section{References}

A Brief History of Lamas and Monasteries from East Ujimqin Banner, Xilin Gol League. At: Private collection of N. Bokhkhad. (In Mong.)

Agvaanlavsüm. Monastic Scholars and Research Articles on Source Studies. D. Narantsetseg (ed.). Ulaanbaatar: Admon, 2015. 691 p. (In Mong.)

Bökeqada, Jadamba. Üzemchin Legends. Xilinhot, 1989. 356 p. (In Mong.)

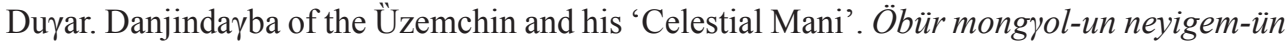
sinjilekü uqayan. 1987. No. 4. Pp. 26-34. (In Mong.)

Duyar. Molom Rabjampa: Biography of the Üzemchin Lama. Department of Culture and History, Administrative Office of East Ujimqin Banner. Uliyasutai, 1990. 106 p. (In Mong.)

Jirüken-ü tolta-yin tayilburi: A 18th Century Mongolian Grammatical Writing. P. Baldanzhapov (text prep., transl., etc.). Ulan-Ude: Buryatia Book Publ., 1962. 136 p. (In Mong. and Russ.)

Lhamusürüng. The Golden Mirror That Clearly Explains Laws of Mongolian Writing. Ikh Khüree, 1913. (In Mong.)

Manduqu Ü. About Danzindagva - the author of the composition Oytaryui-yin mani. In: A study of the Mongolian language. Hohhot: Inner Mongolia Education Press, 1990. Pp. 198-210. (In Mong.)

Pagva T. Cover of the Heart: Analysis of the Commentary Revisited. Ulaanbaatar, 1995. 58 p. (In Mong.) 
Punsag A. Mergen Khambo Sanzhaa-Ishzhamtso of the Üzemchin: One tax exemption document revisited. In: Üzemchin Studies. D. Narantsetseg (ed.). Ulaanbaatar, 2017. Pp. 164-170. (In Mong.)

Punsag A. Molom Rabjampa of the Üzemchin: One biographical source revisited. In: Üzemchin Studies. Hohhot: Inner Mongolia Culture Press, 2006. Pp. 411-417. (In Mong.)

Rinchin N. Distribution of Gems of Supreme Faith in Mongolia (Mongol-Inhabited Territories): A Review of the Tradition Titled 'Melodious Sound'. Xylograph. At: Center of Oriental Manuscripts and Xylographs, Institute for Mongolian, Buddhist and Tibetan Studies (SB RAS). Mongolian Collection. File BM-658. 27 p. (In Mong.)

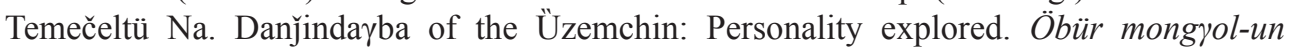
neyigem-ün sinjilekü uqaүan. 1984. No. 3. Pp. 18-28. (In Mong.)

Tomortogoo D. The Commentary on 'Cover of the Heart' Called 'Celestial Mani' That Removes Darkness of Confusion: A Grammatical Writing by 18th Century Alasha Scholar Danzandagva Rabjampa. Ser. 'The Historical Traditions and Theoretical Foundations of Mongolian Linguistics'. Ulaanbaatar: People’s Publ. House, 1981. 162 p. (In Mong.)

Tserensodnom D. Molom Rabjampa Danzandagva's Commentary on 'Cover of the Heart' (by Bogdo Choidzi Odser) Called 'Celestial Mani' That Removes Darkness of Confusion. In: Treasures of Mongolian Linguistics. Ulaanbaatar: Mönkhiyn Üseg, 2021. Pp. 55-94. (In Mong.) 